\title{
A NATURAL HYBRID BETWEEN TWO TROPICAL FISHES: SEMAPROCHILODUS INSIGNIS X SEMAPROCHILODUS TAENIURUS (TELEOSTEI, CHARACOIDEI, PROCHILODONTIDAE)
}

MAURO CESAR LAMBERT DE BRITO RIBEIRO

Interespecific hybridization has become a rather widespread phenomenon among fish groups (Hubbs, 1955). The incidence of natural hybridization among freshwater fishes seems to be a function of environment, decreasing gradually from north temperate to tropical zones. It also appears to be inversely correlated with diversity and therefore, in the tropical highly diverse fish fauna of the Amazon region, only a low frequency of natural hybrids may be expected. However, it is probable that in this region some hybrids have already been studied and identified as distinct species while others are still to be discovered. This paper concerns ecological and morphological aspects of three Amazonian forms of the genus Semaprochilodus Fowler (Characoid, Prochilodontidae) and provides evidences on this respect.

Semaprochilodus insignis (jaraqui escama grossa) and $S$. taeniurus (jaraqui escama fina) are two median size, sympatric species of high abundance in Central Amazonia. During their extensive and complex migrations (Ribeiro, 1983) a third cryptic species (jaraqui-açu) was found in a very low frequency (1:880 individuals) mixed to individuals of both species but never in isolated schools. In the beginning of the annual floods schools of mature males and females of both species of jaraquis were captured in Rio Negro migrating downstream to spawn in the turbid waters of Rio Amazon. Mature males of jaraqui-açu were also found in these schools. Females of jaraqui-açu were never captured in the spawning area nor were they found in state of sexual maturation throughout the year.

In this paper 54 individuals of $S$. insignis, 48 of $S$. taeniurus and 42 of jaraqui-açu were used for the morphological study of these three forms. All individuals were collected with non-selective beach seines from schools migrating in Rio Negro. All measurements and counts were based in the last review of the genus Semaprochilodus (Mago Leccia, 1972). The amplitudes of variation and means of body proportions and counts are presented and they were analized by the method of overlap of means (Royce, 1957). The differences between two means were tested in terms of common standard deviation of samples and the value of three standard deviations was taken as indicative of interspecific differences between two samples. This value corresponded to $13 \%$ of overlap between the samples and the percentage of characters distinct at this level constituted the interspecific differenciation degree.

The following comparisons can be obtained from Table 1:

The jaraqui-açu is neither so elongated as $S$. taeniurus nor so deep as S. insignis. In this new form, its back is but little more elevated than in this first species but not sharply so as in the former. Post dorsal region not so straight so that upper profile is sinous and forms an obtuse angle at origin of dorsal which is intermediate as compared to both species. Lower profile more or less evenly convex. Therefore, body shape is neither smooth and linear as in S. taeniurus nor rhomboid as in S. insignis. Dorsal, anal, pectoral and pelvic fins are inserted in an intermediate position in jaraqui-açu as compared to $S$. insignis (behind) and $S$. taeniurus (in front). Body coloration is similar to that of $S$. insignis especially in the reddish pectoral and pelvic fins. The number of black bands in each lobe of caudal fin in jaraqui-açu (3-6) is intermediate between that of $S$. taeniurus (3-5) and $S$. insignis (3-7). All 


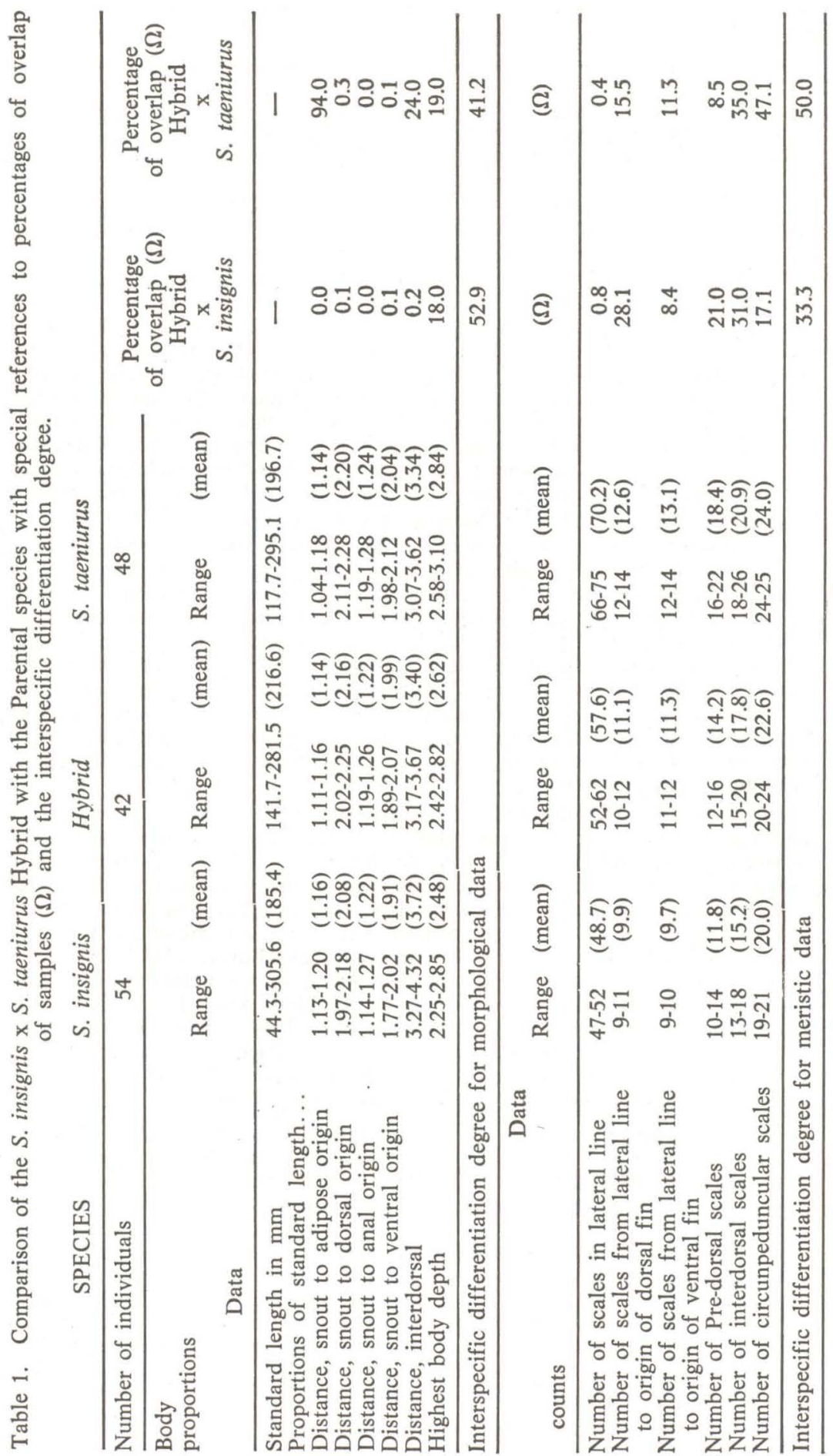


counts of number of scales in jaraqui-açu proved to be intermediate between $S$. insignis (less scales) and $S$. taeniurus (more scales). In conclusion, the jaraqui-açu is almost totally intermediate in morphological characters between $S$. insignis and $S$. taeniurus. The majority of these characters overlap considerably with one and/or other species and if they are morphometrically more related to $S$. taeniurus ( $41 \%$ of differentiation), they are meristically more similar to S. insignis (33\% of differentiation).

According to the literature (Hubbs. 1920, 1940, 1955; Daget, 1963; Daget et al., 1978; Pépin et al., 1970) interme liacy in external characters of jaraquiaçu, as well as their low frequency in the population and the fact that at least their females seem to be sterile, lead to the conclusion that they are natural hybrids between $S$. insignis and $S$. taeniurus. Hybridization in this case may be attributed to chance meeting between sperm and egg. The peak of reproductive activity of both species is 20-30 days apart but in an intermediate period they overlap in different proportions in the spawning area. The scarcity of one species coupled with the abundance of the other could then lead to crossing of the species lines.

Acknowledgments: The Brazilian Research Council (CNPq) provided the necessary funds for this research. The collection of the data was done when the author was a graduate student in the course of Fish and Fisheries of the National Institute of Research for the Amazonia (INPA) and University of the Amazon (Manaus, Brazil).

\section{REFERENCES}

Daget, J., 1963. Sur plusieurs cas probables d'hybridation naturelle entre $\mathrm{Ci}$ tharidium ansorgii et Citharidium distichodoides. Mém. IFAN, Dakar 68: 81-83.

Daget, J. \& Kovassi, 1978. Sur un hybride probable d'Alestes (Pisces, Characidae) dans le lac de Kosson (Côte d'Ivoire). Ann. Univ. Abidjan (Écol.) 21: 33-38.

Hubbs, C. L., 1920. Speciation in the fishes of the genus Menidia. Evolution 2: 306-313.

Hubbs, C. L., 1940. Speciation of fishes. Amer. Nat. 4: 198-211.

Hubbs, C. L., 1955. Hybridization between fish species in nature. Syst. Zool. 4(1): $1-20$.

Mago Leccia, F., 1972. Consideraciones sobre la sistemática de la familia Prochilodontidae (Osteichthyes, Cypriniformes), con una sinópsis de las especies de Venezuela. Acta biol. venez. 8(1): 35-96.

Pépin, H., G. Moreau, S. Marazzato \& J. Géry, 1970. Biométrie d’un hybride naturel de poissons cyprinides, la brème de Buggenhagen. Ann. Hydrobiol. 1(1): 43-54.

Ribeiro, M. C. L. B., 1983. As migrações dos jaraquis (Pisces, Prochilodontidae) no Rio Negro, Amazonas, Brasil, 192 pp. Tese de Mestrado, Instituto Nacional de Pesquisas da Amazônia, Manaus.

Royce, W. F., 1957. Statistical comparison of morphological data. U. S. Fish Wildl. Serv., Spec. sci. Rep. Fish. 208: 7-28. 